\title{
PLANKTON INVESTIGATION IN
} INLET WATERS ALONG THE COAST OF JAPAN -XIII.THE PLANKTON OF OBAMA BAY ON THE JAPAN SEA COAST-

\author{
$\operatorname{AUTHOR}(\mathrm{S}):$ \\ Yamazi, Isamu
}

\section{CITATION:}

Yamazi, Isamu. PLANKTON INVESTIGATION IN INLET WATERS ALONG THE COAST OF JAPAN -XIII.THE PLANKTON OF OBAMA BAY ON THE JAPAN SEA COAST-. PUBLICATIONS OF THE SETO MARINE BIOLOGICAL LABORATORY 1954, 4(1): 103-114

ISSUE DATE:

1954-11-20

URL:

http://hdl.handle.net/2433/174496

RIGHT: 


\section{PLANKTON INVESTIGATION IN INLET WATERS ALONG THE COAST OF JAPAN \\ XIII. THE PLANKTON OF OBAMA BAY ON THE JAPAN SEA COAST"}

ISAMU YAMAZI

Seto Marine Biological Laboratory, Sirahama

With 9 Text-figures

As to the benthic and foraminiferal communities of Obama Bay, three papers have already been published by HABE et al (1945 and 1946) and MORISHIMA (1948) respectively. The writer made a plankton survey of the same bay on October 19 th, 1953. The field work was carried out with the help of gentlemen of Obama Fisheries High School to whom the writer wishes to express his hearty thanks. He is also indebted to Prof. D. MiYadi, Dr. H. Utinomi and Dr. T. Tokioka for advices and valuable suggestions in preparing this paper.

\section{Hydrological Conditions}

Obama Bay is a small baylet on the southern coast of Wakasa Bay (Fig. 1). It is about $15 \mathrm{~km}$ long in the $\mathrm{E}-\mathrm{W}$ and $7 \mathrm{~km}$ in the N-S direction, and has a rather narrow entrance (about $2.5 \mathrm{~km}$ across) between the capes Nokogiri-saki and Matugasaki. The entrance is about $30 \mathrm{~m}$ deep, while the central area of the bay is $10-20 \mathrm{~m}$ deep; Aoto-inlet on the west and Nisizu-inlet on the east are largely less than $10 \mathrm{~m}$ deep. A small river, consisting of two branches Kita- and Minamigawa, flows into the bay from the southern coast of Nisizu-inlet.

Water temperature (Fig. 2, A): The water temperature at the surface was varied from $20.8^{\circ} \mathrm{C}$ to $22.5^{\circ} \mathrm{C}$, a little lower in the western Aoto-inlet to the southern coast than in the central area and in the eastern Nisizu-inlet.

Salinity (Fig. 2, B and C): The salinity in the surface layer was a little lower in both inlets where a small river pours into the bay than in the central part of the bay. In the $5 \mathrm{~m}$ layer it was uniformly higher than at the surface, ranging from 31.5 to $32.3 \%$, although it was nearly the same in both layers at the western Aotoinlet ( 30 to $31 \%$ ).

1) Contributions from the Seto Marine Biological Laboratory, No. 243.

Publ. Seto Mar. Biol. Lab., IV (1), 1954. (Article 11) 


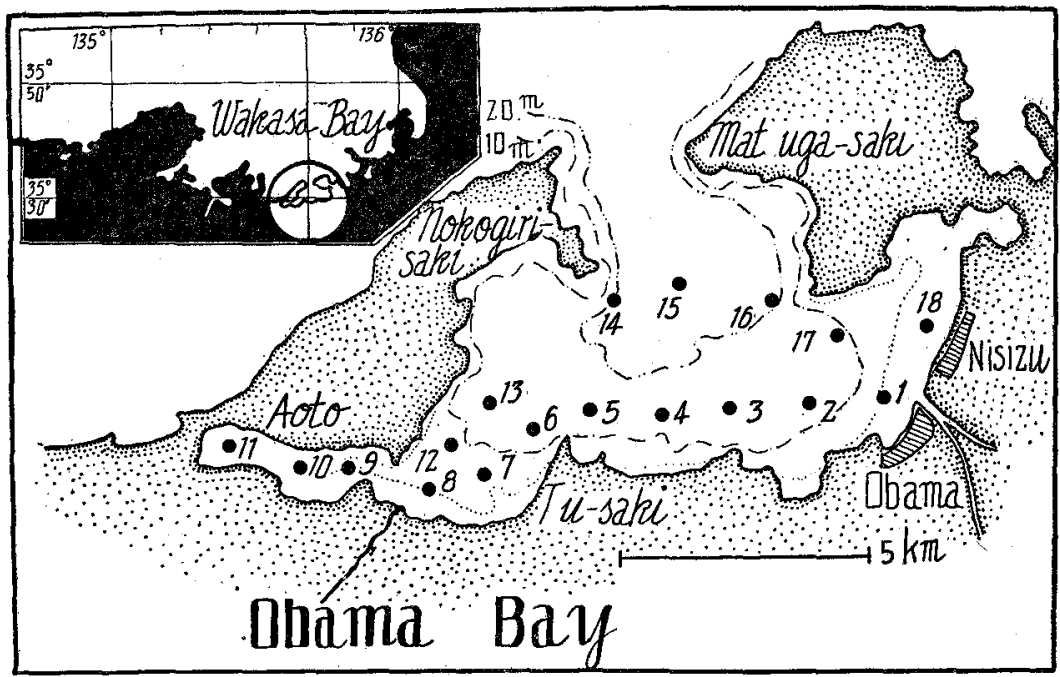

Fig. 1. Map of Obama Bay showing stations and bathymetric contours.

Transparency (Fig. 2, D): The transparency of water was very small at all stations, measuring only $1.5-5 \mathrm{~m}$, particularly smaller in both inlets.

Catalytic activity of sea water (Fig. 3, A and B): At the surface of the western Aoto-inlet the activity was less than that at the surface of the eastern inlet, except at stations near the estuary. In the central area of the bay it was relatively low. In the $5 \mathrm{~m}$ layer the activity was relatively higher than at the surface.

\section{Plankton}

\section{A. Quantitative Analysis of Plankton}

The settling volume of plankton in this bay was lower than in Turuga Bay, as varied from 0.01 to $0.05 \mathrm{cc}$ per one meter haul (Fig. 3, C), and was larger in the Nisizu- and Aoto-inlets than in the central area of the bay. The total number of individuals, cells or colonies of the plankton was largest in the eastern inlet, being about 6 thousands per one meter haul. The smallest number was measured in the western inlet, where the diatoms were especially scarce (Fig. 3, D and Fig. 5, B). Fig. 5, A (above) shows in a graphical form the correlation between the settling volume and total number of plankton per one meter haul. The two curves each for number and volume, are nearly parallel except in the eastern (Sts. 1 and 18) and western inlets (Sts. 8, 9, 10,11 and 12), where the zooplankton was markedly richer in number as well as in volume (Fig. 5, A and B). The zooplankton was evenly scarce in the central area of the bay, being 100-300 individuals per one meter haul. The phytoplankton was richest in the mouth of the eastern inlet and decreased towards 


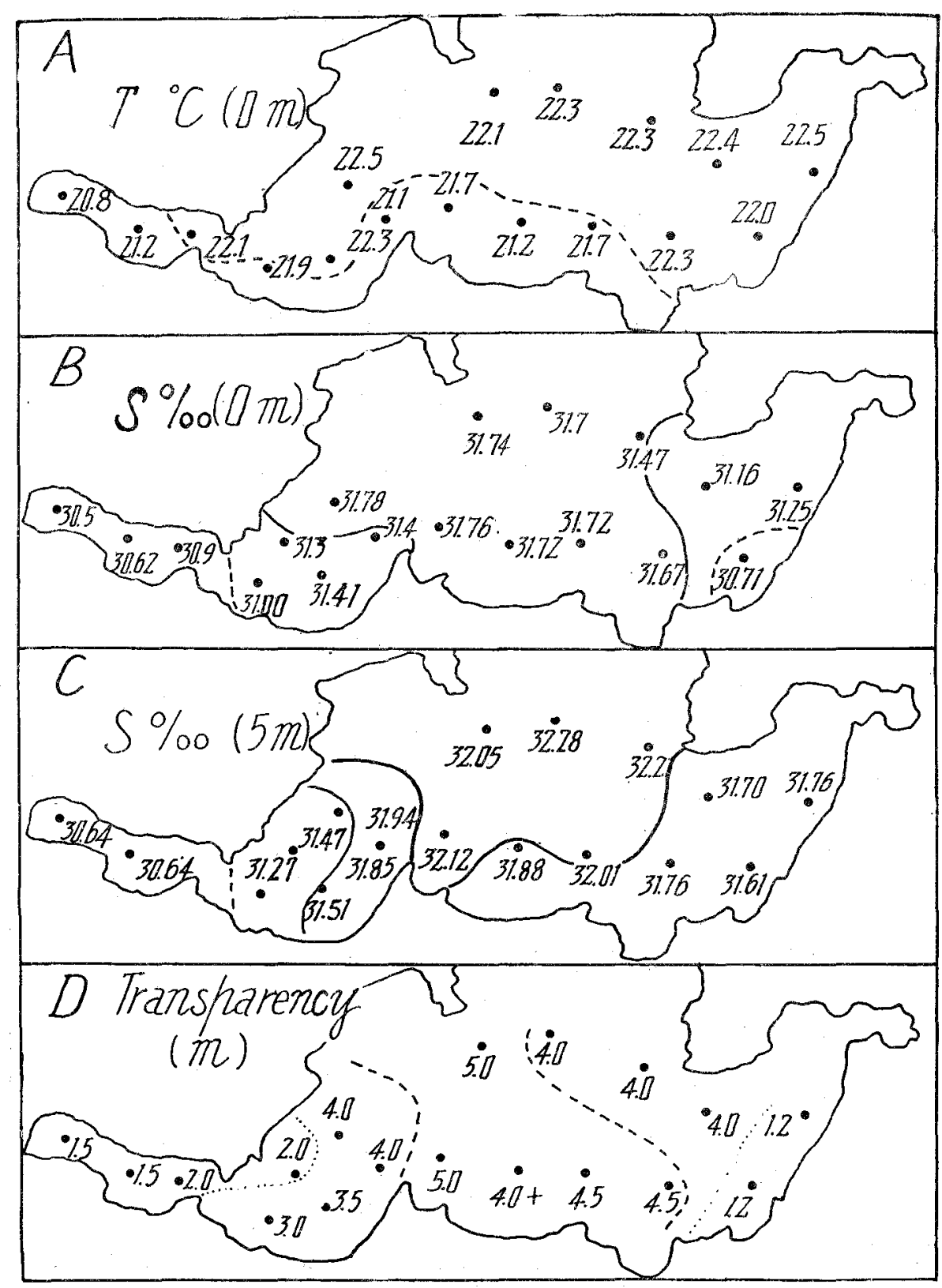

Fig. 2. Distribution of hydrological conditions.
A. Water temperature at the surface.
B. Salinity at the surface.
C. Salinity in the $5 \mathrm{~m}$ layer.
D. Transparency. 


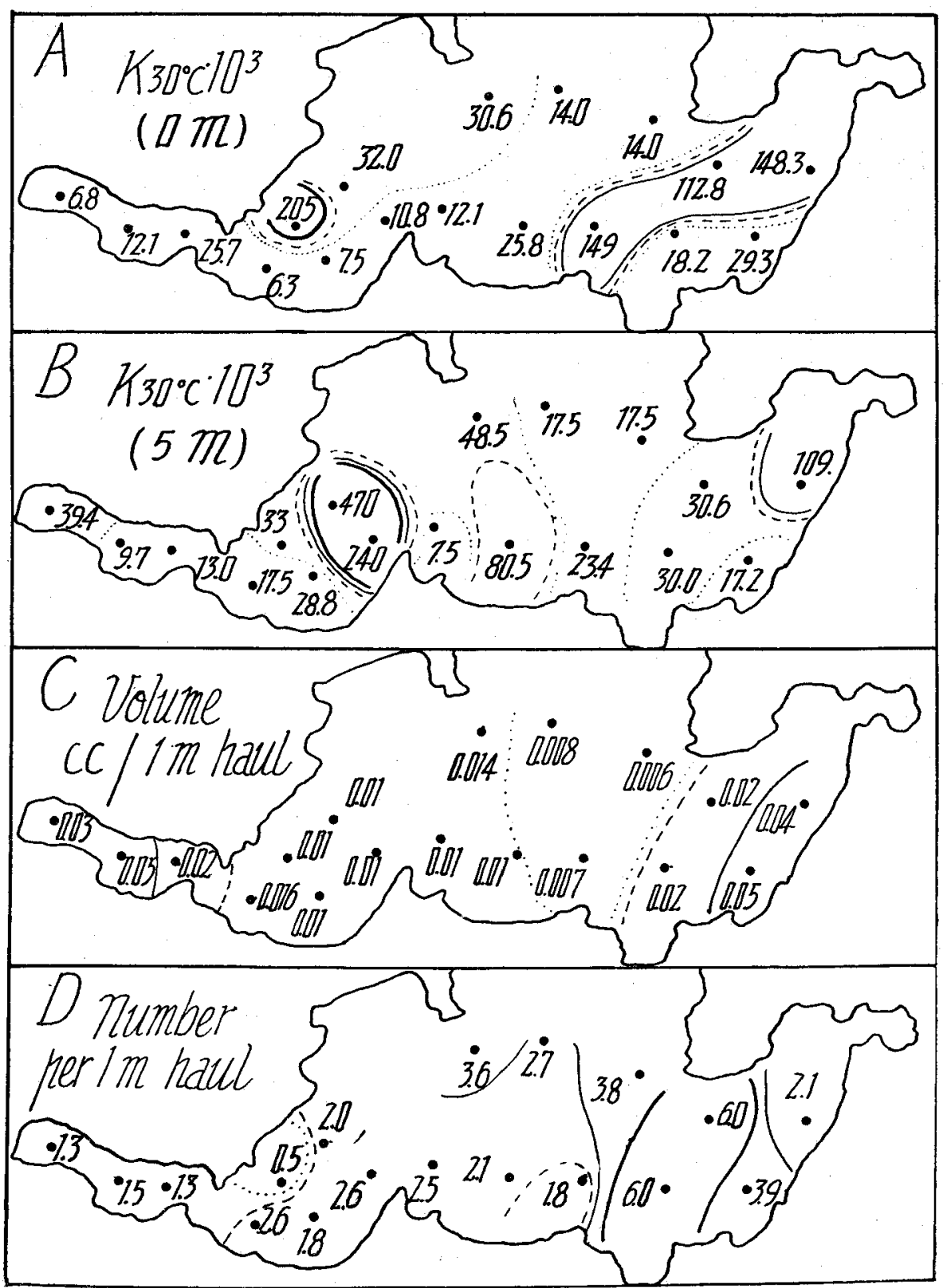

Fig. 3. Distribution of catalytic activity of sea water at the surface (A) and the $5 \mathrm{~m}$ layer $(\mathrm{B})$.

Settling volume of plankton per one meter haul from the bottom to the surface (C) and total number of plankton (Unit of number is thousand) (D). 


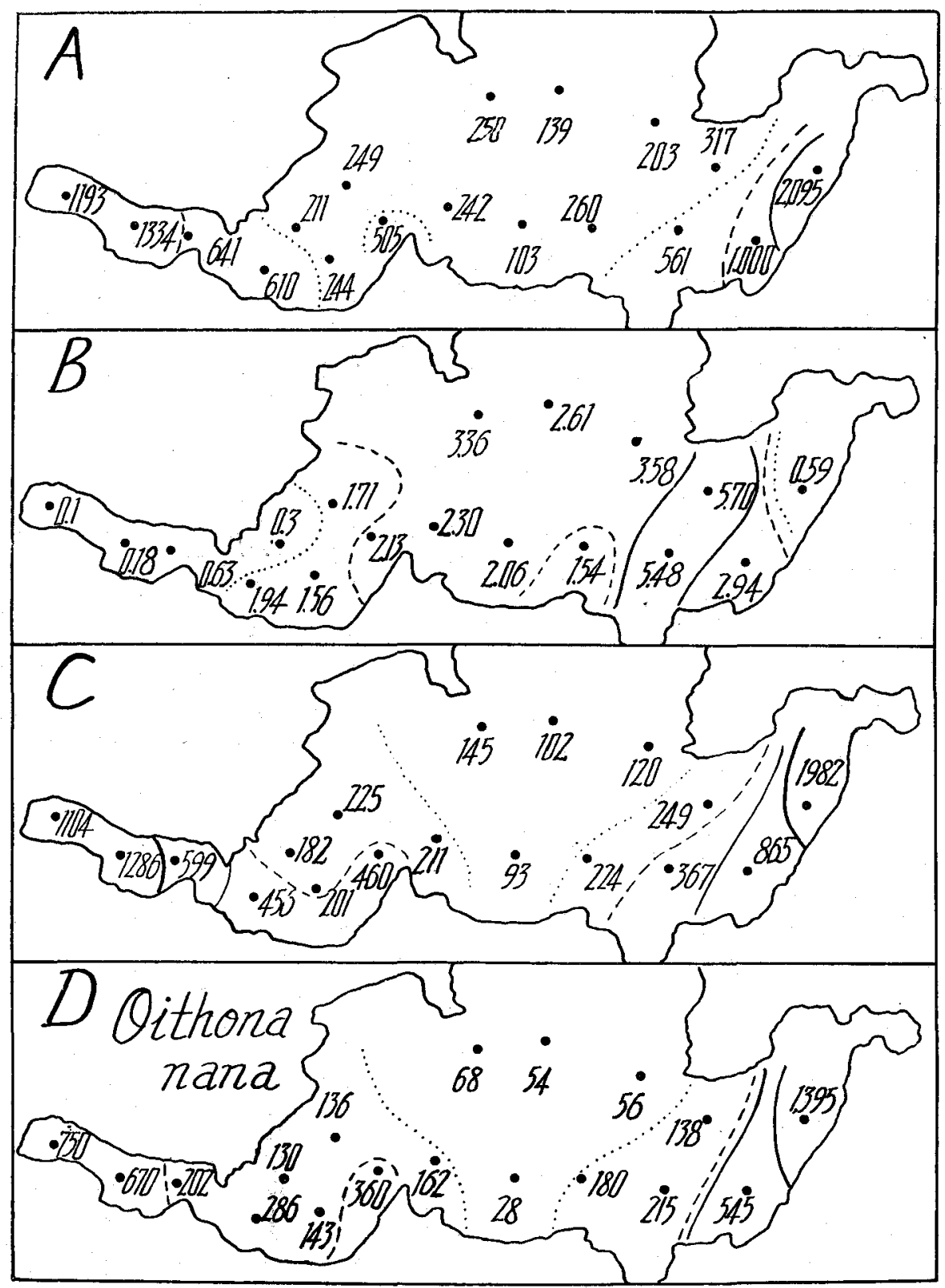

Fig. 4. A. Distribution of total number of zooplankton per one meter haul.

B. Total number of cells or colonies of phytoplankton.

C. Total number of copepods.

D. Distribution of a copepod Oithona nana. 

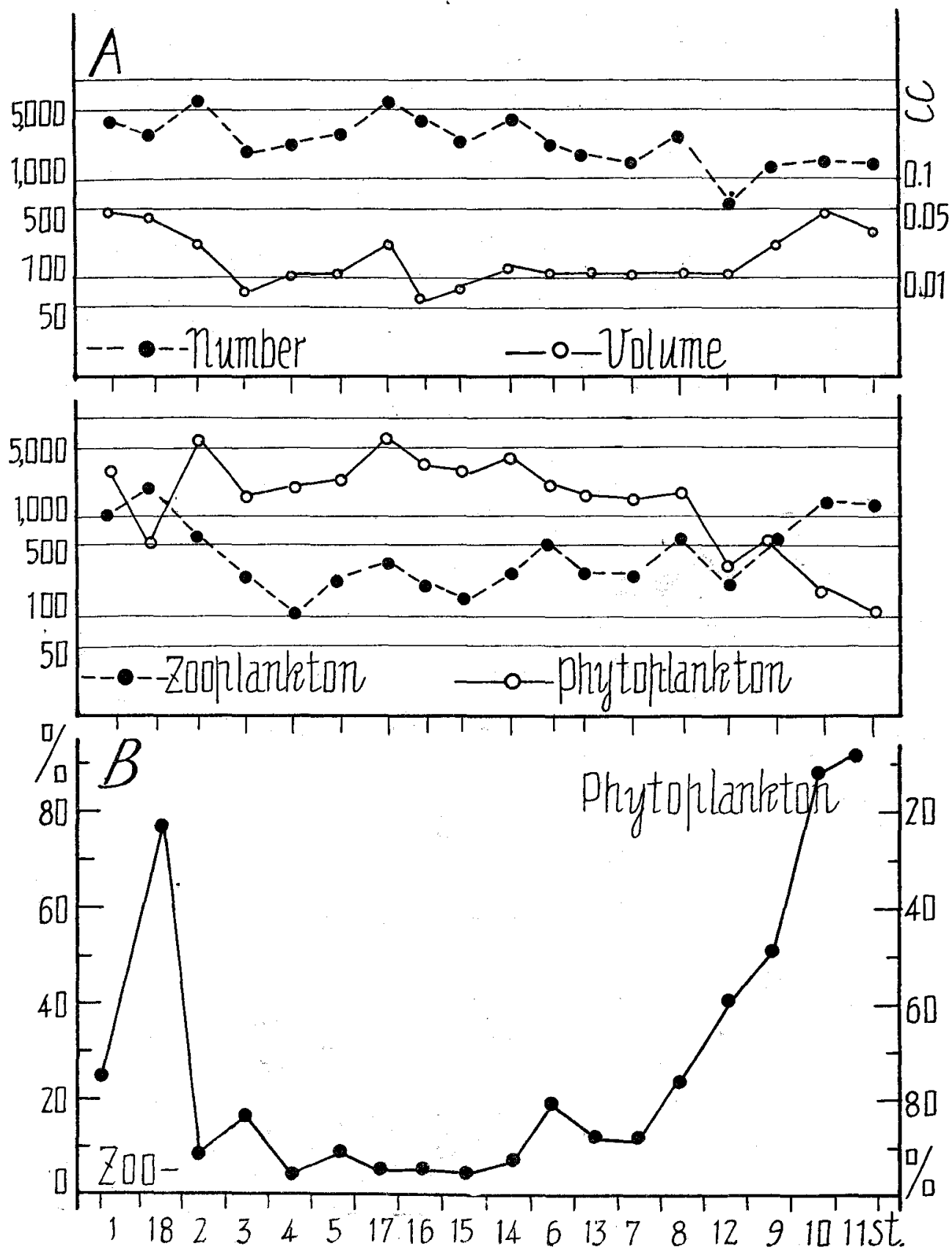

Fig. 5. Correlation between settling volume and total number of plankton in the bay (A, above) and that between total number of zoo- and phytoplankton ( $A$, below). Percentage composition of zoo-and phytoplankton (B). 
the mouth and western inlet of the bay. The numerical percentage of zooplankton in total plankton was very large in both inlets; it showed 20-80\% in the eastern inlet and 8-90\% in the western inlet (Fig. 5, B). While it was smallest in the central area, only $4-10 \%$.

\section{Quantitative Analysis of Plankton}

\section{ZOOPLANKTON}

The copepods, larval forms, protozoans and other animals, including cladocerans, tunicates, chaetognaths and medusae, were dominant groups among zooplankton. Copepods were represented by $90 \%$ of total zooplankton at Sts. 18, 4, 6, 13, 9, 10 and 11 , by $80 \%$ at Sts. $1,3,4,5,7,8,12$ and 17 , and by $60 \%$ at Sts. 2,4 and 16 (Fig. 6, bottom). Of copepods, Oithona nana and Paracalanus parvus were most abundant throughout the stations. Other copepods were only less than $10 \%$, they were Acartia clausi, A. spinicauda, Euterpe acutifrons, Oithona similis, Microsetella norvegica, Micro. rosea, Oncaea venusta, O. media and Corycaeus sp.

Oithona nana was as usual more numerous in the inlets than elsewhere, and it was represented by 50 to $80 \%$ of total copepods at almost all stations (Fig. 4, D and Fig. 8).

Paracalanus parvus, more stenohaline than Oithona nana, was similarly distributed in the bay, and densest in both inlets.

Acartia clausi and A. spinicauda which are principally inhabitants in somewhat estuarine waters of inner bays such as Kozima Bay (YAMAZI, 1954a), were very scarce in this bay, although they occurred widely (Fig. 7, B).

Microsetella norvegica, $M$. rosea and Euterpe acutifrons were very small in number and percentage composition (Fig. 7, C and D). The other copepods, such as Calanus minor, Oithona plumifera, Oncaea venusta, Oncaea media, Corycaeus flaccus and Corycaeus sp. were sparse. The fact that these species as well as $O$. similis and Microsetella were found only in the central area of the bay suggests that they were immigrants from the outer bay, namely Wakasa bay.

\section{Phítoplankton}

The Phytoplankton was very poor throughout the stations as compared with the zooplankton, being only less than 6 thousands per one meter haul even at the richest station (St. 17). The main diatom species in the bay were Thalassionema nitzschioides (100-1500), Nitzschia seriata (less than 300), Chaetoceros didymus (less than 1000), Ch. Lorenzianus (less than 300), Ch. curvisetus and Bac. hyalinum. The other 24 diatoms were all neritic species and occurred very sparsely. The dinoflagellates were also poor in number. The main species were Cer. trichoceros (less than 100), C. molle (less than 25), C. tripos (less than 30), C. pennatum (less than 15), C. fusus (less than 30) and small number of Pyrocystis noctiluca, Peridinium grande, $P$. depressum, $P$. oceanicum var. oblongum, C. palmatum var. ranipes, C. candelabrum, C. smatoranum and Ceratocorys horrida. 


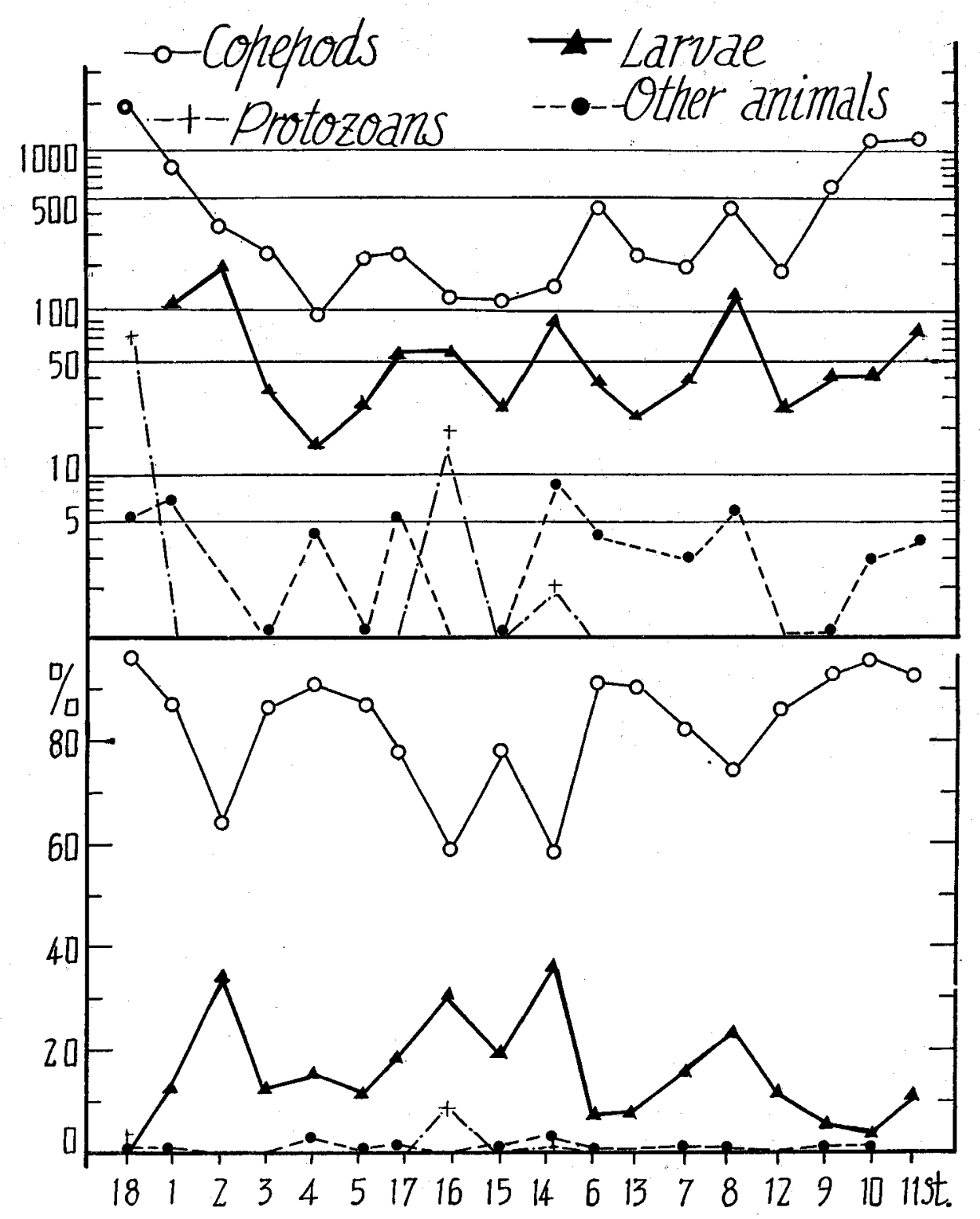

Fig. 6. Population of zooplankton groups per one meter haul (above) and their percentage composition (below). 


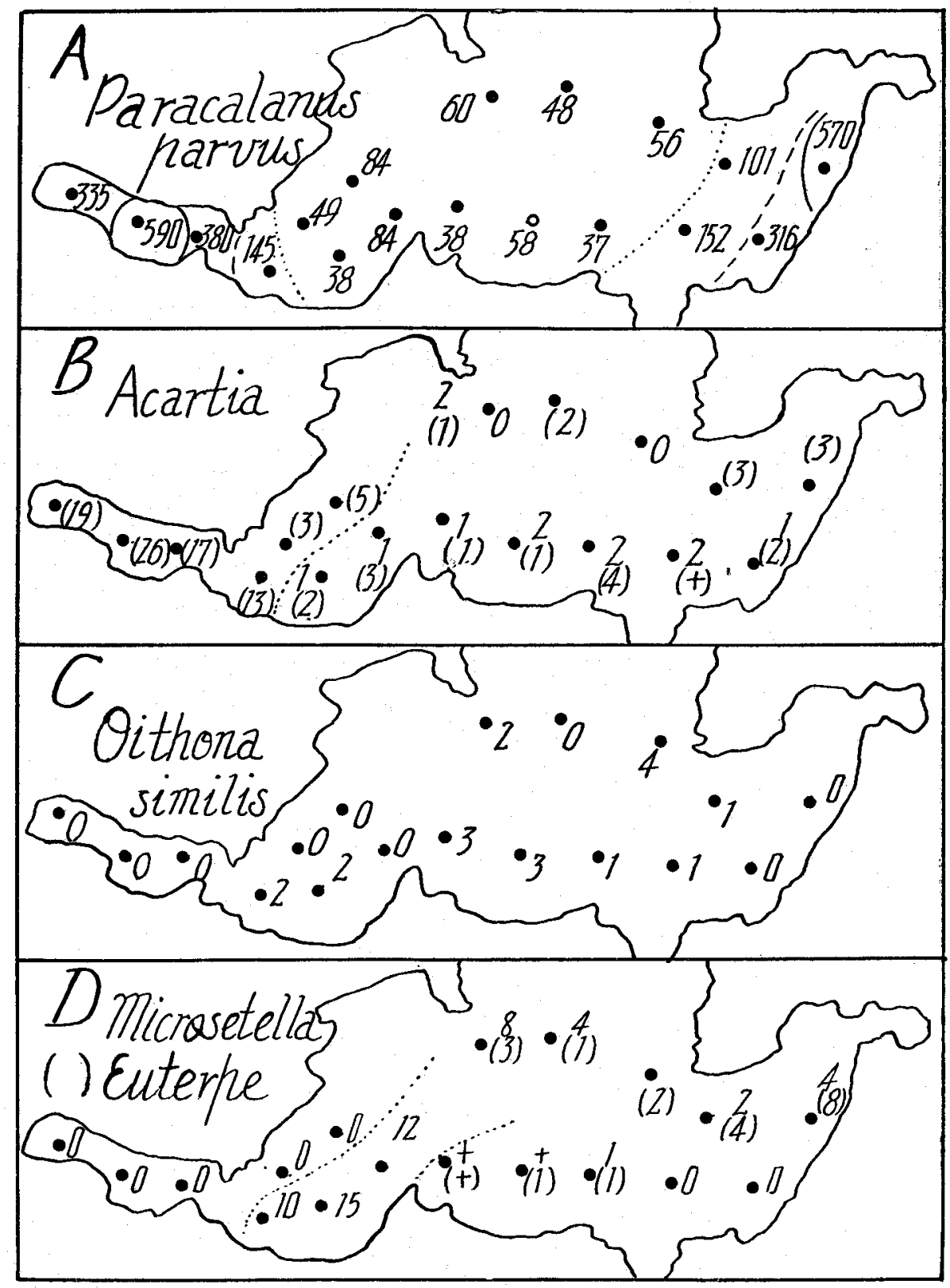

Fig. 7. Distribution of important copepods. 


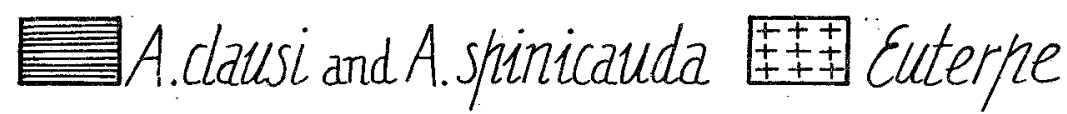

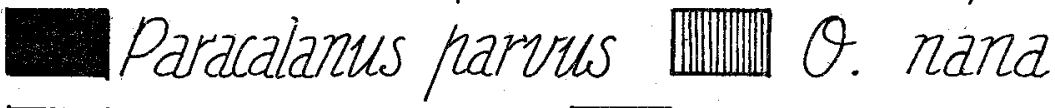

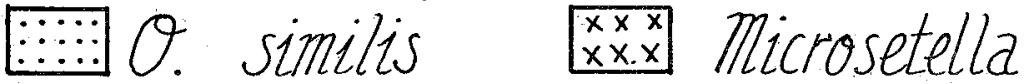
渴 Oncaea 国 Corycaelus $\square$ Dthers

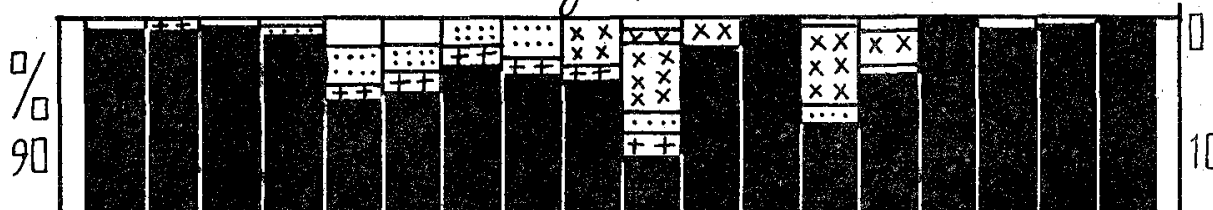

80

70

60

50

40

30

20

10

10.
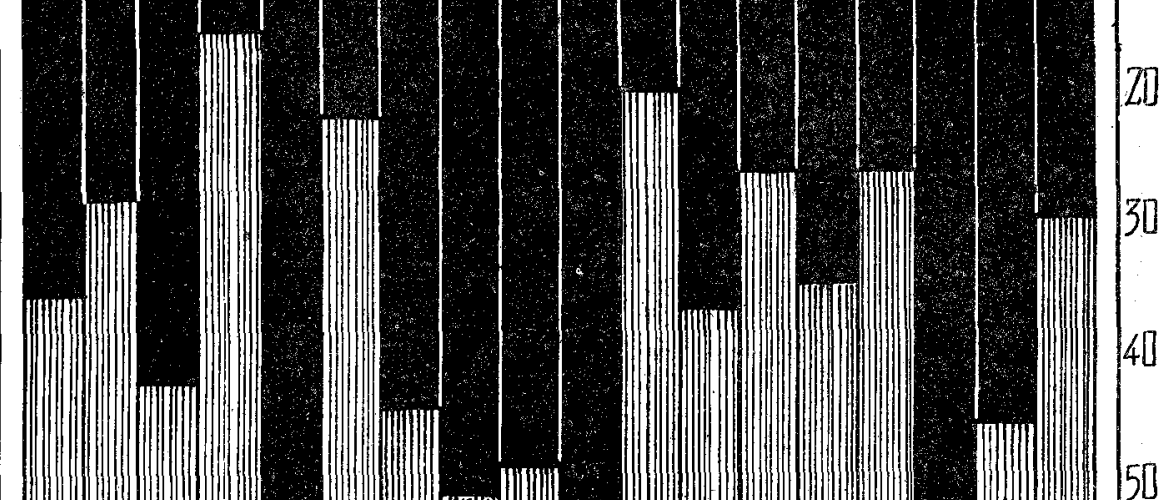


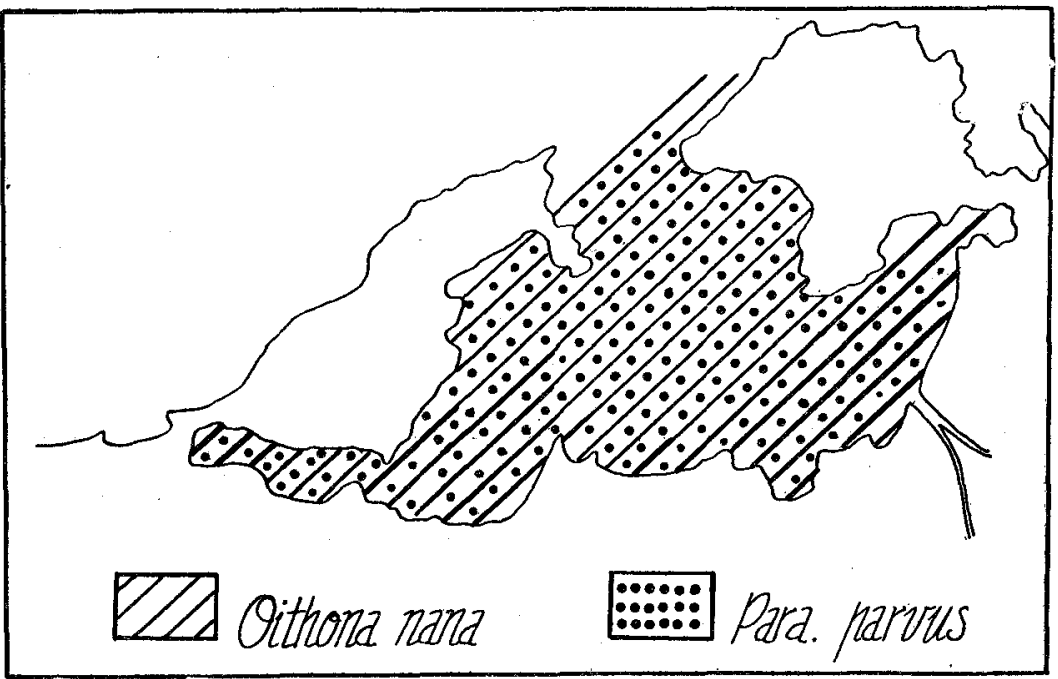

Fig. 9. Distribution of dominant copepod communities in Obama Bay.

\section{Consideration and Conclusion}

Obama Bay is a secondary baylet of a large-sized Wakasa Bay. Its entrance is narrow, so that the water in the bay is relatively stagnant. The plankton components in the bay are also different from those of the open sea water. The most important plankton in the bay is copepods, and the distribution of the dominant copepods in percentage composition and their number shows that the copepod fauna of the bay may be safely recognized as Oithona nana-Paracalanus parvus community, in which the following two faciations are discernible on differences found in the distribution of associate plankters :

The narrow areas of the western and eastern inlets showing low salinity and small transparency are cccupied densely by Oithona nana. This copepod is associated with a large number of copepod nauplii, Paracalanus parvus and a small number of A. clausi, A. spinicauda, Euterpe acutifrons and Oithona similis. The diatoms and dinoflagellates are few in number.

The central area of the bay is also occupied by Oithona nana-Paracalanus parvus mixture nearly in the same percentage composition as in the first faciation, but here some oceanic dinoflagellates are relatively larger. The population density in this area is smaller than in two inlet arecs, although number of species is larger. The water of this area is rather similar to that of the inner region of Wakasa Bay (YAMAZI, 1954 b) and shows sightly higher salinity than in two inner inlets as mentioned previously.

Furthermore it may be noticeable that the two estuarine species Acartia clausi and A. spinicauda are widely distributed in nearly the whole area of the bay, although few in number. 


\section{REFERENCES}

HABE, T. et al: 1945. Studies of benthic thanatocoenoses of Obama Bay, Prov. Wakasa. Kyoto Daigaku, Seiri-Seitai Kenkyû Gyôseki, No. 32 (In Japanese).

HABE, T. et al. 1946. Benthic communities of Obama Bay and their relation with the catch by dredging. Ibid., No. 55 (In Japanese).

Morishima, M. 1948. The accumulation of foraminiferal tests in inlets of Wakasa Bay on the Inland Sea of Japan. Rept. Com. Treatise on Marine Ecol, and Paleoecol., Nat. Res. Coun., Washington, 1947-1948, pp. 89-91.

YAMAZI, I. 1954a. Plankton investigation in inlet waters along the coast of Japan. XI. The plankton of Kozima Bay in the Seto-Naikai (Inland Sea). Publ. Seto Mar. Biol. Lab., Vol. 3, no. 3 , pp. 399-421.

1954b, Idem., XIV. The plankton of Turuga Bay on the Japan Sea coast. Ibid., Vol. 4, no. 1, pp. 115-126. 